\title{
Cancer In Organ Transplant Recipients
}

Akademisk avhandling

Som för avläggande av medicine doktorsexamen vid Sahlgrenska akademin, Göteborgs Universitet, kommer att offentligen försvaras i föreläsningssalen Hjärtats aula, Blå stråket 5, Göteborg

Fredagen den 17 september klockan 9:00

av Caroline Stenman

Fakultetsopponent:

Professor Tomas Lorant, Uppsala Universitet, Sverige

Avhandlingen baseras på följande delarbeten:

I. Stenman C, Gonzalez H, Gillstedt M, Dellgren G, Hasséus B, Holmberg E, Rexius H, Öhman J, Paoli J. Degree of differentiation of cutaneous squamous cell carcinoma: a comparison between a Swedish cohort of organ transplant recipients and immunocompetent patients. Dermatol Pract Concept. 2018;8(4):330-336.

II. Stenman C, Gillstedt M, Barck L, Gonzalez H, Halldin C, Wallinder A, Paoli J, Osmancevic A, Claeson M. Sun protection behaviour in organ transplant recipients and non-transplant patients attending a dermatology outpatient clinic in Sweden: a questionnaire survey

Accepted for publication in: Photodermatology, Photoimmunology \& Photomedicine.

III. Stenman C, Wallinder A, Holmberg E, Karason K, Magnusson J, Dellgren G. Malignancies and Heart Transplantation- a Single Center Long-Term Outcome Study.

Submitted manuscript.

IV. Stenman C, Wallinder A, Holmberg E, Karason K, Magnusson J, Dellgren G. Malignancies and Lung Transplantation- a Single Center Long-Term Outcome Study.

Submitted manuscript. 


\section{Cancer In Organ Transplant Recipients}

\section{Caroline Stenman}

Institute of Medicine, Sahlgrenska Academy, Gothenburg, Sweden 2021.

\section{ABSTRACT}

Tens of thousands of transplantations are performed around the world each year. Organ transplant recipients (OTRs) are obliged to receive life-long medical treatment with immunosuppressive drugs to ensure graft function. However, such medications entail an increased risk of developing a broad spectrum of malignancies, especially skin cancer.

Study I: The aim of this study was to investigate the degree of differentiation of Squamous cell carcinoma (SCC) in OTRs compared to immunocompetent individuals. The degree of differentiation refers to how cancer cells look and function compared to normal cells. Data from the Swedish Cancer Registry were cross checked with data from the Transplant Registry. Only patients with a diagnosis (SCC, Basosquamous Carcinoma and/or SCC in situ) from the Department of Dermatology, SUH, between 2002-2010 were included. The control group consisted of those who were diagnosed with the same diagnosis at the same time period at SUH as OTRs. No significant differences were observed in the degree of tumour differentiation in SCCS appearing in OTRs compared to those in the control group $(p=0.4)$. Study II: The aim of this study was to investigate whether specialized OTR clinics with dermatological follow-up, as has been suggested, provide additional benefit. In this study, in total, 696 OTRs and non-TPs completed a sun exposure questionnaire between 2011 and 2015. The control group, the non-TPs, were recruited among outpatients at the Department of Dermatology. We compared OTRs with dermatological follow-up to OTRs with no followup. Fewer OTRs than non-TPs had experienced $\geq 1$ sunburn in the past year ( $20 \%$ vs $46 \%$ $\mathrm{p}<.0001)$. There were more frequent users of sunscreen among OTRs with follow-up than among other OTRs (63\% vs $44 \%, p=.006$ ). Thus, OTRs reported less sun exposure compared to non-TPs, consolidating the positive effect of sun protection advice following transplantation.

Study III. In this study we investigated cancer incidence and survival in 664 patients who underwent heart transplantation (HTx) at SUH between 1985-2017. Data was retrieved from SCR and the Cause of Death Registry. The median follow-up time was 7.7 years. We found in total 231 malignancies in 138 patients. Of all patients, 19\% had experienced malignancy after almost 7 years after HTx. We found an overall risk of cancer to be 6.2-fold higher than the general population and 2.9-fold higher when excluding NMSC.

Study IV. The aim of this study was to investigate cancer incidence and survival in 614 patients who underwent lung transplantation (LTX) at SUH between 1990-2016. Data was retrieved from SCR and the Cause of Death Registry. The median follow-up time was 5.1 years. We found 159 malignancies in 111 patients which corresponds to $18 \%$ of the total study population. We found an overall risk of cancer to be 5.6-fold higher than the general population and 2.8-fold higher when excluding (NMSC).

Keywords: Organ transplantation, cancer, survival, the degree of tumour differentiation, sun protection behaviour. 